\title{
Contemporary Business Trends and Industrial Transformation in Slovenia on the Examples of Maribor and Celje
}

\author{
Đukičin SmiljanaA*, Milanković JelenaA, Đorđević Jasmina ${ }^{A}$ \\ Received: May 2011 | Revised: July 2011 | Accepted: August 2011
}

\begin{abstract}
The topic of this paper is contemporary tendencies and business trends in Slovenia, a country which left behind the period of crisis and by transforming its outdated and obsolete industry has overcome the period of transition. The paper deals with economy, industrial and economic solutions in Slovenia thanks to which this country has recovered from post-socialistic crisis and thus ranked among European and world's competitive countries. The examples of Maribor and Celje illustrate the fact that though medium sized centres, they can achieve good results by clever investment and planning. Serbia, which is still in the period of crisis, could be governed by the example of Slovenia on its path of development. This paper provides just some of the examples that Serbia could resort to. The issues which Serbia has been facing for a certain period of time could be overcome by adequate investment, building up of the infrastructure, economy transformation and industry modernization.
\end{abstract}

Key words: industry, transformations, Slovenia, Serbia, Maribor, Celje, technopolis

\section{Introduction}

The collapse of political system in the Eastern Block countries during the second half of I989 ushered a new period, commonly referred to as post-socialism. The goal of the 1989 revolution was to undo the old system by tearing down the tenets of a crumbling political and industrial structure. While the main principles of the transition-reestablishment of private property rights, free market economy, and industrial transformations-were quite clear, their implementation was proven in history to be a difficult task. Eastern Europe seemed destined to transform itself into a version of open society, marching to the unknown through trial and error, joining the quilt of European cultures, all moving in the same direction, yet each following its own path (Stanilov, 2007). Globalization and urbanization processes demand both the transformation of geographical territories and adaptation of economy and industry to the new conditions (Lorber, 2005). Many countries do not follow those contemporary trends (Lorber, 2005). Slovenia is definitely an outstanding example of how once a lagging and outdated industrial country has been transformed into a modern and competitive one. Of all the countries in the region Slovenia is the one which by its work, wise investment and good strategy has achieved the level which all surrounding countries should aspire to (Lorber, 2005). Despite the decrease of the number of people employed in industry, it records the increase of production owing to upgraded industry, construction of the industrial parks, infrastructure and adequate investment in economy (Bole, 2008a). Serbia has had a very difficult time with transitional changes, which has affected the economy as well as the other sectors. In Serbia the crisis has been accompanied by the production decrease, inadequate investment, political turmoil, a high unemployment rate and the whole set of social issues (Grčić, Ratkaj, 20o6). On its way through transition, Serbia should follow the example of Slovenia, and the industrial centers of Serbia could follow the examples of Maribor and Celje in the process of its development. The business-industrial zone Tezno in Maribor is the largest zone of the kind in Slovenia and being so is attractive

\footnotetext{
A Faculty of Sciences, Department of Geography, Tourism and Hotel Management, University of Novi Sad, Trg Dositeja Obradovica 3, 21000 Novi Sad, Serbia

* Corresponding author: Đukičin Smiljana, e-mail: smiljanadjukicin@gmail.com
} 
to developers, thus recording a steady increase in production. It is characterized by a successful cooperation with major enterprises (www.conatezno.si). This paper illustrates the way Slovenia has overcome the period of transition and crisis and become a modern industrial country attractive to investments. It also shows the guidelines for Serbia on its path towards the economy rise.

\section{Global Business Trends and Industrial Transformation}

Recently there have been big changes in the sector of industry and economy. The processes of industrialization and urbanization have been encouraging the flow of the population and the activities in particular centers (Tošić, Đorđević, 2004). The recent changes comprise deindustrialization, the process which had taken place in Western counties long before it took place in the surrounding countries which until recently were under the socialistic regime. Deindustrialization is a modern process which is occurring along with the transformation of industrial sector in the conditions of globalization and technical advances. A regional economic integration, transfer of technology and knowledge, the increase of the world trade, the new attitudes towards raw materials, are just some of the basic characteristics of global interaction in postindustrial society, whereas environmentally safe production, new materials, a high technology linking of the system "science-technology-production", the creation of technological parks, a highly organized production and others are the characteristics of the reconstructed production (Miletić at al., 2009). Globalization and improvement of technique are the characteristics of the postindustrial age. Deindustrialization means the process of human work force reduction in industry, but it does not diminish the importance of people in it. A successfully transformed industry will employ fewer people, but at the same time the production will be larger and more efficient (Rowthorn, Ramaswamy, I999). In developed countries industry is defined by a reduced number of unqualified workers and increased number of highly qualified ones, who make a small group in a large number of countries (Rowthorn, Ramaswamy, I999).

\section{Contemporary Business Trends and Industrial Transformation in Slovenia}

A highly specialized and technologically developed economy demands a wide range of services including science and research and modern financial, commercial, accounts and others (Bole, 2008a).

The increased participation of employees in services is the only acceptable realistic explanation for the cut in the number of workers employed in industry. A highly specialized and technologically well equipped industry requests a well developed service sector which belongs to tertiary human activities and whose increase is reported in all developed countries including Slovenia (Rabvar et al., 2005). Transition in general has generated a crisis of industry in all post-socialistic European countries, but nowhere else was the crisis so tumultuous and destructive as it was in Serbia. Due to economic, political and transitional issues, the situation in Serbia was such that in the " 8 os the number of workers employed in industry was around I,000,00o whereas twenty years later that number was reduced by one half. This was not the result of upgraded and modernized industry, but of the tremendous changes in politics, regional development policy as well as the increase of unemployment rate and more expressive social differences (Grčić, Ratkaj, 2006).

The reduction of work force in industry has created a need for building up of modern factories with high technical and technological demands in which work force will be replaced by technology, whereas human work force will be used in the tertiary sector. Modern and well equipped industrial and technological installations are being built like industrial, technical and technological parks in which the production is significantly increased and human activity has ceased to be material. This model of immaterial production and activities in the tertiary sector are currently named "cultural revolution", and its functioning is enabled by modern IT (Bole, 2008b). A faster process of industrialization is possible to achieve provided the transport and railway infrastructure are good, and the industry and employment market, i.e. the investments and resources well coordinated (Lorber, 2006). This development can be slowed down by various indistinctive factors such as strategy variation of the local authorities (government), local market and the issue of the uncoordinated activities between industrial centers and the resources, bad infrastructure, etc (Grčić, Ratkaj, 2006). Transport is a significant factor in the formation of industrial regions and drive axes that are supposed to connect regions instead of building boundaries between them (Grčić, Ratkaj, 2003). Transport issues as well as many others that Serbia is facing, have caused the industrial regression in comparison with Slovenia, which has managed to achieve a higher level than Serbia owing to a good organization in industry.

A significant factor of development on state, regional and town scope is industry, so a great attention should be paid to its location. Well developed areas with properly built infrastructure, abundance of work force and facilities for developers are preferable compared to less developed 
regions. On the other hand, building up of a production installation in an unprivileged region would mean a turning point and the possibility of a faster development (Lončar, 2008). A significant attention should be paid to the location of an industrial zone, which in most cases, was inherited from the previous period. Also, environment issue is equally important since industrial companies in the past were not environment conscious and therefore, green areas were not built near industrial and technological installations. Likewise, industrial or technological zones should not be built in the vicinity of settlements and in that way environmental standards and principles would be respected along with building up of the protective green areas or zones. Also, the direction of dominant wind, by which industrial gas exhausts might reach and threaten the local population, has to be taken in consideration (Lorber, 1999). Changes in population, physiognomy and functional structure of the territory occur due to industry and those are the changes that occur in the environment. Industry affects the quality of air, surface and ground water, soil as well as the level of noise in the settlements (Miljanović at al., 2004).

A zone can be located in various regions, but more effective are those built in the frequent international traffic arteries, in river and sea ports as well as in cross-border areas. Local, region$\mathrm{al}$ and state authorities have an important role in their building (Lončar, 2008).
Considering that Slovenia can set an example for the development of industry in Serbia, this paper is meant to emphasize the possibilities for the industrial development of major centers and regions in Serbia on the examples of Maribor and Celje.

The realized transitional effects have changed the "quality" of locations, slackening, not rarely limiting as well, the improvement of one area and at the same time accelerating the development of the other (towns, regions) leading to the increase of regional disparity. While some towns and regions were capable of adjusting successfully to a newly created situation, the other ones are facing major issues, which have considerably weakened their position on local and regional scale (Miletić at al., 2009).

In normal economic circumstances changes in industrial centers depend on their size. However, centers behave differently in transitional countries. The example of Serbia reports that large centers took most of the crisis burden, whereas the small centers appeared more flexible and adaptable to changes. The conclusion is that the most stable are middle sized centers. In the example of Serbia, those centers are: Ruma, Indjija, Smederevo. In large centers changes had a bad impact on the development of industry, which caused stagnation and discouragement in industry (Grčić, Ratkaj, 2003).

The research on the investment activities on the level of regional development shows an excep-

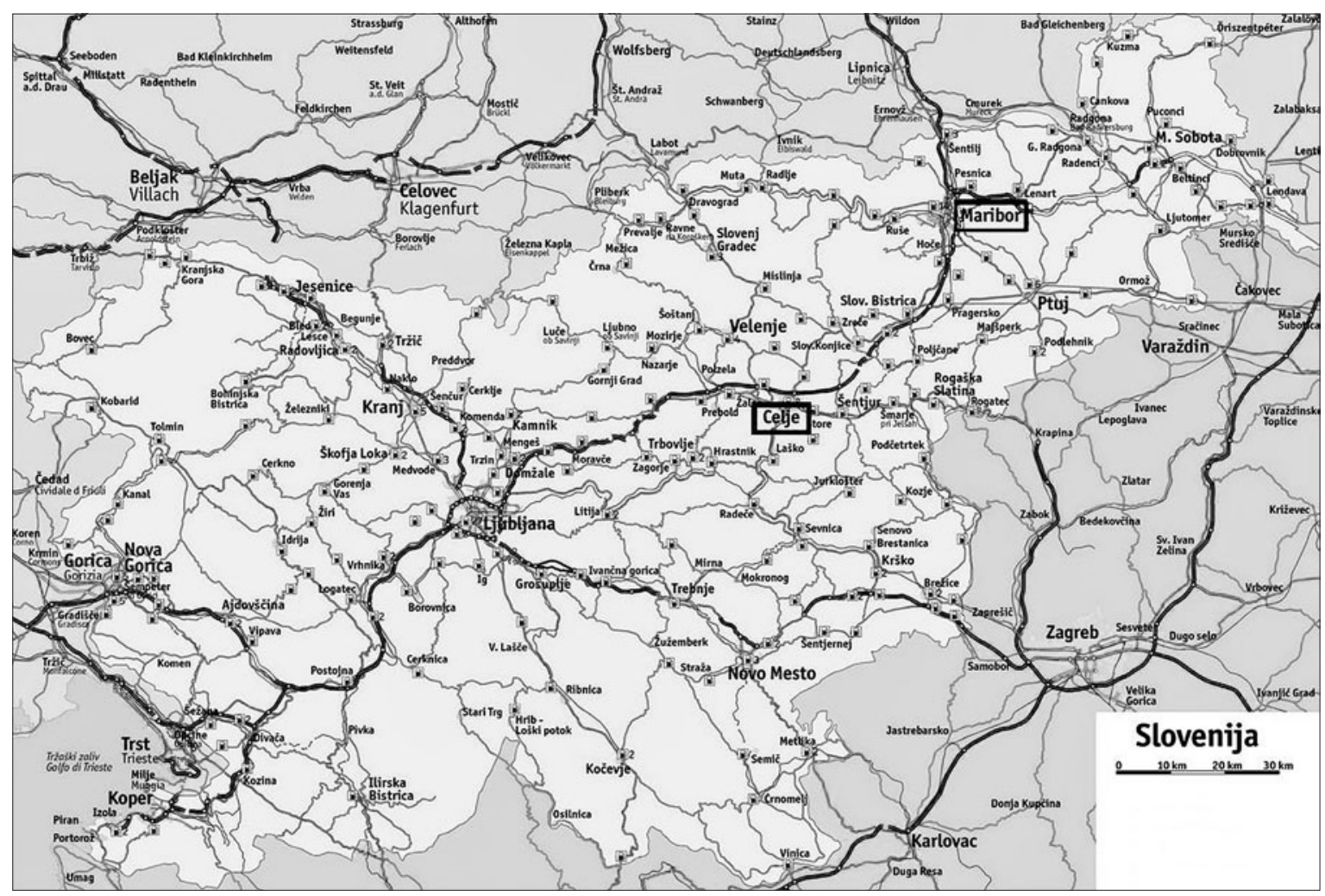

Figure 1. The location of Maribor and Celje in Slovenia

Source: www.dars.si 


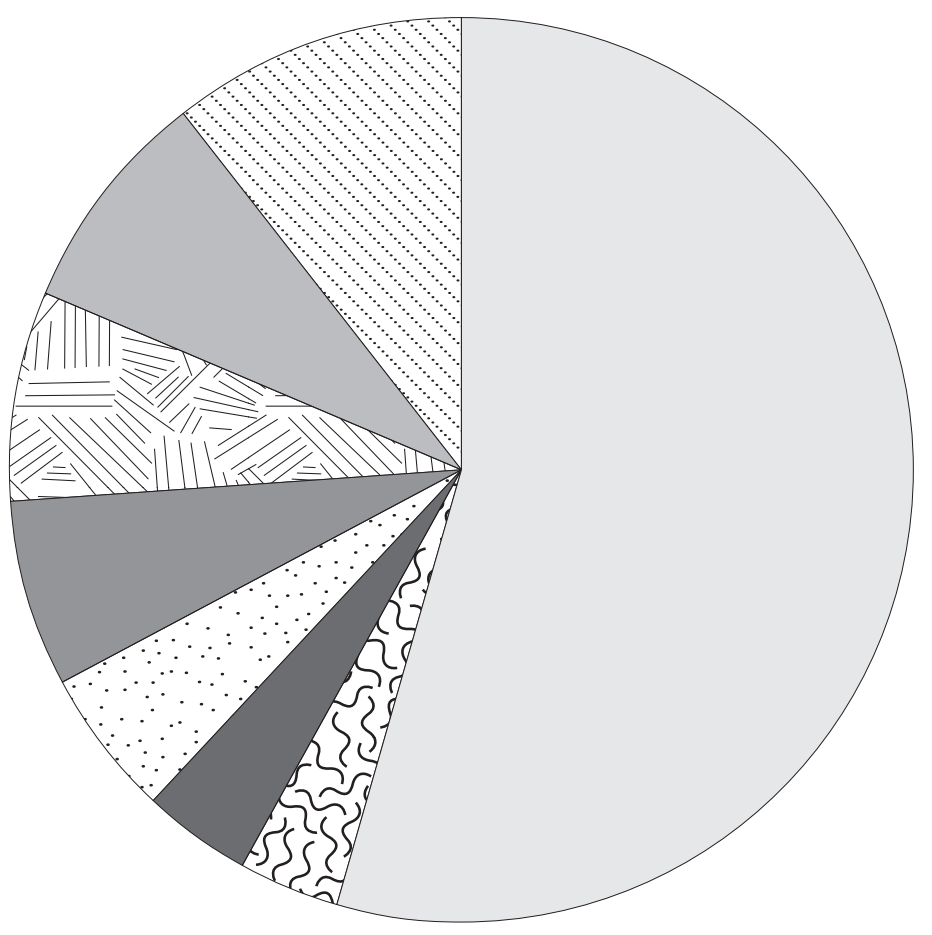

Ljubljana - 54.7\% SJJ Krško-3.5\%

Celje - 6.8\%

Maribor $-10.4 \%$

Figure 2. Municipalities with investment over 500 million euros in the period 2000-2006.

Source: Ravbar, 2009

tional concentration in central Slovenia, where this region with one fourth of the population and just over one third of all businesses reports two fifths of all investments. According to the investment activities, central Slovenia is followed by the regions of Maribor and Celje.

In the past the largest investments were directed to thirty municipalities of Slovenia (I6\%) in which three quarters $(76.6 \%)$ of all investments were noted. Apart from the "strong" municipalities such as Ljubljana, Maribor, Novo Mesto, Kopar and Celje, in which the amount of investments per capita exceeds the average amount, the improvement of the smaller centers such as Kranj, Velenje and Krsko (Ravbar, 2009) is evident.

One of the major characteristics of Slovenia is a wide dispersion of the population in almost 6,000 settlements. Because of the policy of even regional development, this arrangement is based on the polycentric concept of urbanization, which was introduced 30 years ago (Sitar, 2000). The process of industrialization is both economic and social process which had changed the physiognomy and functioning of Maribor in the igth and 2oth centuries. The development of industry and investments affected the population structure, agricul- ture, economic growth and social standard. With its big natural, economic and socio-cultural gravitational area, the industrial town of Maribor was a strong macro regional center. The impact of industry is reflected in the growth of the population in urban centers, and the other result is a decline of agriculture in rural areas (Lorber, 2006). Priorities in urban centers should be the development of production and services as well as the prevention from depopulation in rural areas (Tošić, Đorđević, 2004).

In Slovenia, the regional planning was started in 200I, when the process of decentralization started. Slovenia and the development of the Savinj region have chances to make up for the loss they had had by 2013 through adopting and conducting the National program of development and the Regional development of the Savinje region. Celje is an important economic, transportation, educational and cultural center which realizes the significance of regional integration, for it has successfully carried out numerous projects. Integration is a key to a successful and rapid development (Klančnik, 2006).

\section{Historical Development of the Industrial Zone Tezno in Maribor}

The industrial zone Tezno was formed in I94I and was meant for the purposes of the German war industry. The location was selected by the following factors: an ideal traffic location, industrial and trade tradition and the nearness of the Fala power plant. In the period from I94I-I944 the production in the part of the factory meant for aircraft manufacturing was constantly growing. The number of the employed was estimated to about 7,000. After the World War 2, TAM-Maribor was set up as the first vehicle factory in FNRY (Federal People's Republic of Yugoslavia), which was manufacturing vehicles under the Czech licence "Pioneer". In I96I, the factory was renamed "The Factory for Car and Engines Maribor". In the post war period, up to 1985 , the production of vehicles in TAM-Maribor was steadily growing. The biggest growth of the production was in the period I97II975. From I98I-I985, the production was constantly 9,00o vehicle per year. After I988, political and economic circumstances reflected on the level of the production, which started to fall.

The business-production Tezno Zone (BPZ Tezno) was founded in 1996 when TAM's bankruptcy and put a stop to a years' long agony. After the bankruptcy of TAM, Maribor program reconstruction (MRP) and the Development Fund (predecessor to the Slovenian corporation for development-SDC), merged with the core of the bankrupt company and set up fourteen other enterprises. SDC and the municipality of Maribor formed 
a consortium afterwards which was obligated to buy up all the TAM's property; the municipality of Maribor bought up the infrastructure in I999.

The construction plan for the BPZ Tezno (zone T-5) was approved back in $200 \mathrm{I}$ and at the time presented just a formal legal base for the further development. The current contents of schemes of BPZ Tezno are defined by the regulation regarding the plan draft in 200I. According to the regulation, this area is meant for (Lorber, 2006):

- production and storage activities;

- process linked to logistic activities;

- activities (in the field of transport and communications, business services, agencies, public administration, finance, insurance and other services);

- commercial activities;

- hotel and tourism industry (for the needs of the employed);

- road and railway transport;

- pumps;

- activities regarding postal system and communications;

- parking services

\section{Characteristics, Advantages and Disadvantages of the Tezno and its Economic Perspectives}

The Tezno zone is situated in Maribor, the town located in the heart of Europe, altitude $269 \mathrm{~m}$, on the river Drava and is the center of renowned province Štajerska. Maribor is the second largest urban center in the Republic of Slovenia, the place of the University of Maribor and important cultural institutions with the population of over I0o,00o. The town is situated on the crossroads of the two PanEuropean roads, the traffic corridors-Corridor Io which links Hamburg with Thessalonika and Istanbul, and Corridor 5 which links Lisbon with Kiew. Maribor has an international airport, which provides both regular and charter flights. The airport includes services and training school for pilots from European airlines. There is also a well developed network of training schools and the university which comprises a number of faculties: the School of economics and business, the School of technical engineering, faculties for computer science and information technology, chemistry and chemical technology, civil engineering and transport. This way, the professionals needed for tertiary activities can be educated in Maribor. Maribor is the center of the Podravlje region with the population of 320,000 (www.conatezno.si).

Within such environment, the Tezno zone fits in perfectly, and being located on the south outskirts of town, has made a rapid improvement over the past few years. The Business department in the

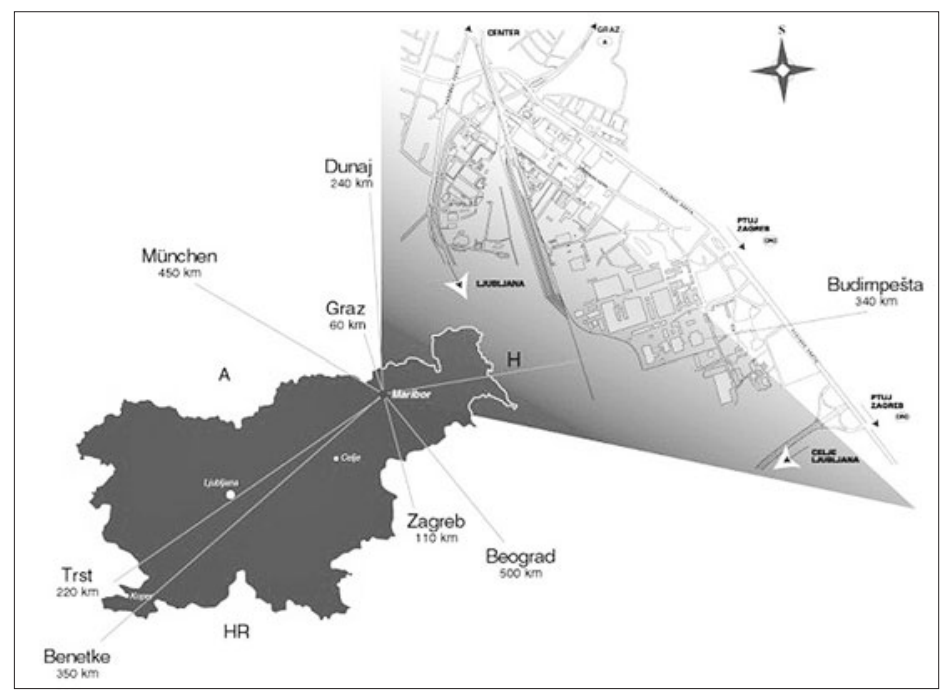

Figure 3. The location of the Tezno zone in relation to the important European locations

Source: www.conatezno.si/o-coni-tezno/

Tezno zone acts as the administrator of Tezno zone and the booster and coordinator of its development. The above mentioned sector takes part in the cooperation of enterprise associates with the zone at competitive prices. Also, it participates in maintenance of collective energy and installations in the Tezno zone and in other related activities. A permanent development of the infrastructure is provided in the Tezno zone and the activities in general promotion and recognition are being taken. The policy of this industrial zone is to offer ideas to developers, meet their demands in making deals, etc. The Tezno is the largest business-production zone in the republic of Slovenia and covers an area of 108 hectares, but there is still an area of about 40 hectares of available space which is at the disposal to investors. This situation is suitable for permanent investment inflow and development. Owing to Corridors Io and 5 it is well connected with other parts of Europe. The zone is provided with all necessary infrastructures and is a reliable supplier of adequate amounts of water and electricity at competitive prices. The initial number of I4 companies in 1996 has increased to more than 160 and in 2007 the number of the employed reached almost 3,500 (www.conatezno.si).

One of the Tezno zone cores is a group composed of enterprises for which the Tezno manufactures modern products and supplies the biggest and best known European and world's car manufacturers such as (www.conatezno.si): Ford, Daimler, Christer, Citroen, Peugeot, Opel BMW, MAN...

The Tezno is the host to domestic "Hi-Tec" manufacturers which successfully compete both in the country and worldwide with their products such as (www.conatezno.si): computer software, designs for "intelligent" installations, develop- 


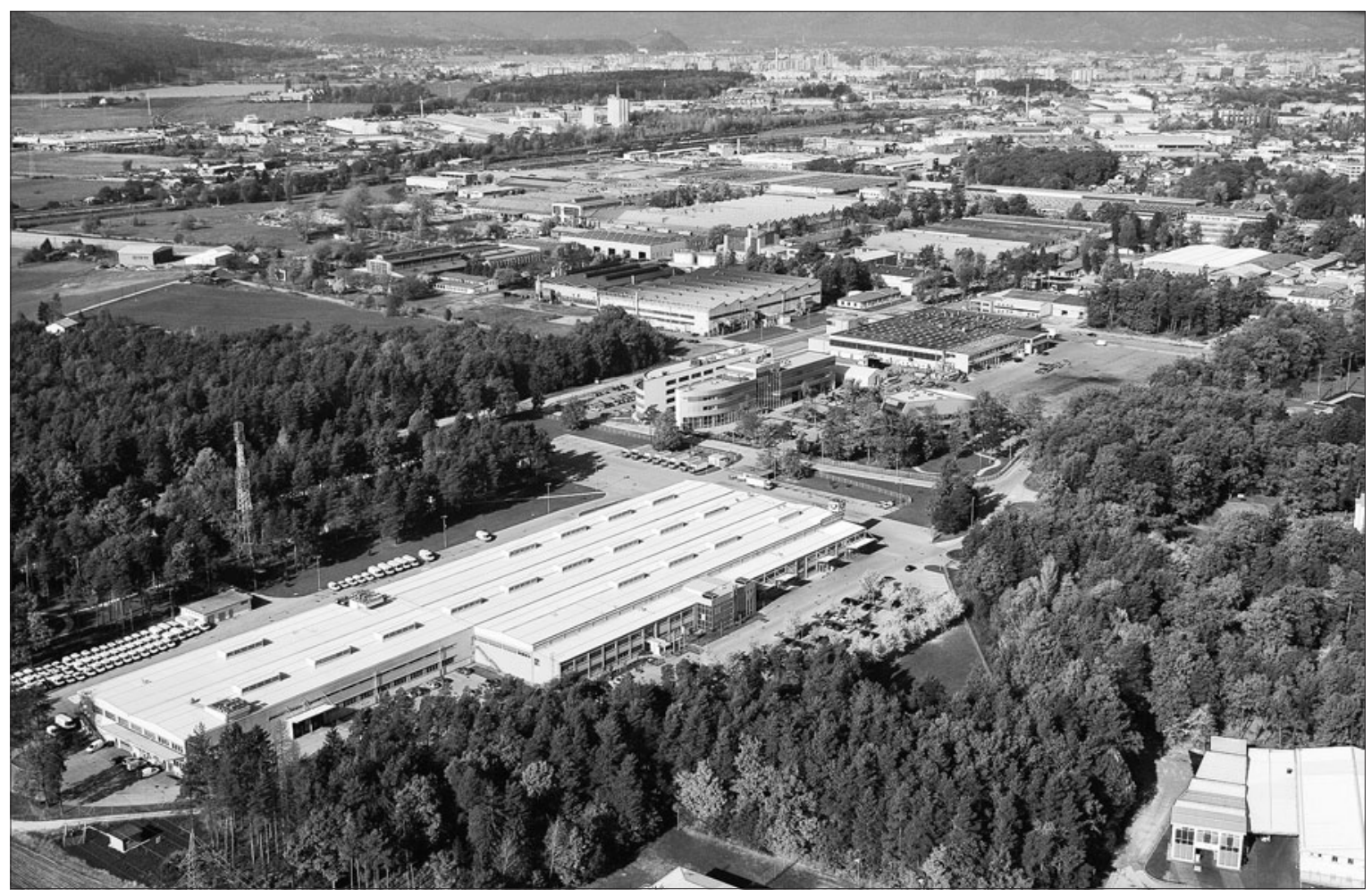

Figure 4. The Tezno, the largest business-industrial zone in Slovenia

Source: www.conatezno.si/uploads/images/Gallery/Sedma-sila/tam11-legen.jpg

ment and designs for devices and systems for economical use of energy, devices and systems for vehicles, boats and ships electricity powered as well as the most advanced machines.

The Tezno is the seat of the major information center of the second largest bank, and one of the largest insurance companies in Slovenia. There are also the headquarters of Slovenian postal services.

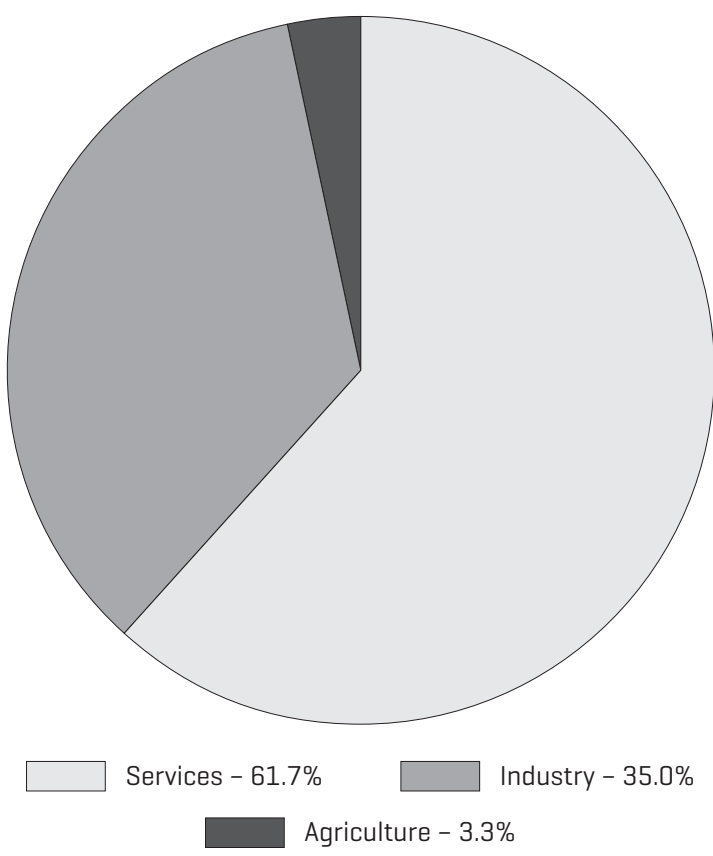

Figure 5. Activity structure in the Podravlje region Source: www.conatezno.si
Owing to high technical and technological equipment, qualified staff, competitive products, reasonable prices and organization in general, the Tezno zone, within the Podravlje region, records high participation in the national gross revenue.

The fact that in the Podravlje region services count to $60 \%$ of the total income (www.conatezno.si) is another proof of its development and a high level of industrialization.

The industry in the Podravlje region counts to $35 \%$ of income whereas agriculture just $3.30 \%$ (www. conatezno.si). The BPZ Tezno was conceived as a driving force to economic and regional development. In the Podravlje regional development program (period 2007-2013), the zone was determined in the program for the increase of entrepreneurship and competitive economy. The program supports planning and endorsement as well as creation of innovative, particularly small, still in the process of development, firms with a high additional value and services based on knowledge (Lorber, 2006). A significant advantage of the BPZ Tezno in attempt to attract new investors is its strategic and geographical position. Maribor has good road and railway links with the port Kopar, situated $220 \mathrm{~km}$ from Maribor. The railroad infrastructure will be enhanced by another line on the route Kopar-Divacha. The location of the zone in the southeast part of town is also favorable. The construction of the so-called "Raod to Ledine" will also have a significant impact on the further development of the 
zone; this road will largely enhance the traffic infrastructure in the zone and provide a larger flow of the traffic to town.

The BPZ Tezno also has some disadvantages which slow down the development. The outdated infrastructure, some of which dates back in the period of World War Il, makes a bad impression on the potential investors since they have to spend large amounts of their investments in renovation, site purchasing and construction of the infrastructure. Generally, the zone appears rather disorderly and not very attractive to the potential investors. Furthermore, it makes the land prices lower. As for Slovenia, the prices of land in the zone are competitive. However, the difficulty is that prices of land in Austria are lower than in the BPZ Tezno and therefore become more attractive in the market. On the other hand, the prices of land in Ljubljana are three times higher than here, so they are more reasonable in this business zone than those in the capital. Within the BPZ Tezno is an institute that manages all available infrastructures for the potential investors and maintains energy and municipal energy supply. The Institute signs annual purchase contracts for power supply (with the company Electro Maribor) and gas supply (with Geoplin company) and since these are big deals, they are made at good prices, which is on behalf of the Tezno. The development of the BPZ Tezno, due to the inflow of new enterprises, has affected the increase in creation of new jobs and consequently decrease of the region$\mathrm{al}$ and town unemployment rate. The fact that in 200 the number of the employed in this area was I,200 compared to 3,000 in 2006 confirms the statement (www.conatezno.si).

\section{The Technopolis Celje-Project of the Present and the Future}

The region of Savinje is the second largest in Slovenia with 252,735 employed and 3,200 companies with 6,000 employers. It has an exceptional location which offers numerous options for market expansion in the Balkans and southeast Europe. It possesses a developed economic and technological infrastructure and stimulates a more rapid development of the regional entrepreneurship offering an inspiring field to foreign developers.

The Technopolis Celje represents the priority project for the whole Savinje region in Slovenia and is of great importance for the development on the national scale. The town of Celje is the third largest town in Slovenia and the largest one in the region Savinje with the population of 50,000 and 690 enterprises. The Technopolis covers an industrial-business area of 690 hectares and is divided into seven subgroups (www. rra-celje.si). The area of the "Technopolis Celje" is situated on $170,000 \mathrm{~m}^{2}$. On that site there are numerous facilities (including those under construction) meant for various purposes such as technological companies, development institutions, technological and educational centers from Slovenia, Europe and the world. The realization of the Tecnopolis project was started in 2003 when the Regional Development Agency, which has always been the initiator of important projects, such as the project the "Technopolis Celje", came up with the idea about a concept of technological town Celje.

The first construction of the Technopolis was put up in 2006 and was financed by the European Union. The Technopolis represents the economic center and is part of the resolution about national development projects for the period 2007-2023.

The goals of the projects are:

- construction of the "town of technology" which will provide long term conditions for the inflow and development of creative class

- create the conditions for global development of the region regarding technology performance and boost its competition based on specialty and innovation capacity

- improve knowledge, establish the cooperative network which will be based on education and international business activities in the region and on a larger scale.

Within the Technopolis seven basic programs stand out and those are (www.technopolis.si);

I. Technological park

2. International university with the student University

3. International center for environment and energy engineering

4. Multicultural center for central and Southeast Europe

5. Creative polis - the town of art and design;

6. International financial and investment center for Southeast Europe

\section{The Technological Park Celje}

Of the total area of the Technopolis, the technological park covers an area of 50,170 $\mathrm{m}^{2}$. On this site another twelve new installations meant for technological companies, development institutions and educational centers from Slovenia and Europe as well, will be constructed (www.tehnopolis-invest.com/index_poslovni_en.php).

Within the Technological park, three basic zones are distinguished and divided as fallows.

A Zone - represents information and communication technology, creative industry and business system. It covers an area of 31,314 $\mathrm{m}^{2}$ where five installations are built. The construction period of this zone is from 2006 to 2016. 
Table 1. The territory of the Technopolis with the details about areas and investments

\begin{tabular}{|l|r|r|r|}
\hline Territory & \multicolumn{1}{|c|}{$\begin{array}{c}\text { Area [m²] } \\
\text { installations [m²] }\end{array}$} & $\begin{array}{c}\text { Value of the } \\
\text { investment [mil.€] }\end{array}$ \\
\hline Technological park & 35,350 & 50,170 & 55 \\
\hline International University & 29,114 & 47,191 & 47 \\
\hline Campus & 6,335 & 27,000 & 20 \\
\hline Environment and energy engineering & 5,005 & 13,837 & 9 \\
\hline Center for quality life & 38,613 & 130,779 & 25 \\
\hline $\begin{array}{l}\text { Multicultural center for Central } \\
\text { and Southeast Europe }\end{array}$ & 26,559 & 25,108 & 130 \\
\hline $\begin{array}{l}\text { Investment and Financial Center } \\
\text { for Southeast Europe }\end{array}$ & 5,352 & 12,843 & 300 \\
\hline TOTAL & 146,328 & 306,928 & \\
\hline
\end{tabular}

Source: www.rra-celje.si

B zone represents a zone of sustainable source of energy and ecology, which is to be built from 2010 to 2017. It covers an area of $26,407 \mathrm{~m}^{2}$ and comprises five installations.

C zone - which is to be constructed in the period from 2013-20I8 and will represent a zone of advanced technology. The area of $25,672 \mathrm{~m}^{2}$ will contain three new installations.

The Technological park Celje, composed of technological companies and development institutions, will be in constant contact with the international University Herman Celjski, thus representing the key to the development and innovative infrastructure, designed for a more rapid development of the Savinje region, and a starting point for technology transfer in Southeast Europe. Specific goals of the project (www.tehnopolis. si):

- create at least 2000 jobs

- increase the level of educational structure from the current $12 \%$ highly educated professionals in the region to $20 \%$ by 2013

- provide the conditions for "intellect" inflow in the region

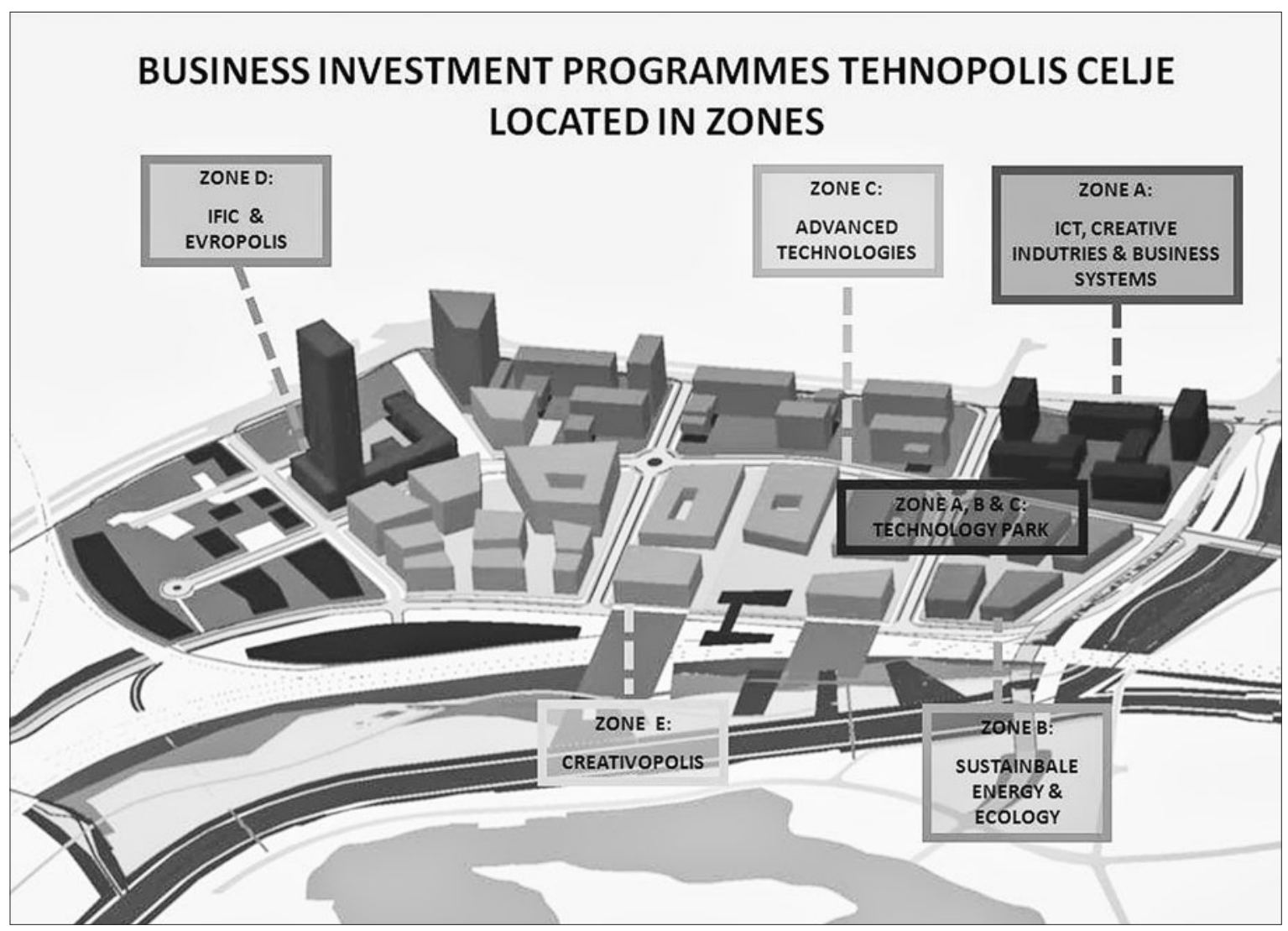

Figure 6. Locations of the zones in the "Technopolis Celje" Source: www.tehnopolis.si 


\section{Conclusion}

Slovenia has set an extraordinary example of how an obsolete and outdated country has been transformed into a modern and competitive one. Industrialization is a modern process which is going on in economic and industrial countries along with the transformation sector in the conditions of globalization and technique advances. Modern and well equipped industrial and technological installations are being built in the form of industrial, technical and technological parks in which the production is considerably increased and human activities have ceased to be material.

Compared to other countries of the former SFRY, Slovenia has come the longest way regarding political, industrial, and economic development. Its advances can be explained by establishing organized and upgraded industry, developing regional and local centers and good links between them, by clever investment and efforts made to achieve European standards. This is the path that Serbia should take, starting with the transformation of economy by developing small and medium sized centers and investing in modernization of industry and infrastructure. The other issues that should be considered are the level of technical and technological equipment, professional staff, competitive products and reasonable prices. Maribor and Celje are and should be notable for their complete economic, industrial, transport and educational centers of international importance, whose example could be adopted by the centers in Serbia. The essential principals for a sustainable economic development imply territorial dimension of economic, environmental, political and legislative relations and are aimed to bring to balance the development of towns and regions. Only by planning, a long term observing the situation, and elimination of the defects can the capital multiply.

\section{Acknowledgments}

The paper is part of the project (project contract: I76020) financed by the Ministry of Education and Science, the Republic of Serbia.

\section{References}

Bole, D. 2008a. Cultural industry as a result of new city tertiarization. Acta geographica Slovenica 48, 2, 255-276.

Bole, D. 2008b. Geographical aspects of the economic transformation of Slovenian urban areas. Doctoral Thesis. Department of Geography Faculty of Arts, University of Ljubljana. Ljubljana. (In Slovenian)

Grčić, M., Ratkaj, I., 2003. Euroregions and eurocorridors as factors of integration of South
Eastern Europe with the European Union. Proceedings of Faculty of Sciences-Geographical Institute 5I, I-22. (In Serbian)

Grčić, M., Ratkaj, I., 2006. Structural changes and regional differentiation of industry in Serbia during the period of transition (I988-2005). Bulletin of the Serbian Geographical Society 86,2, 97-II2. (In Serbian)

Klančnik B., 2006. Regional Development Programme Savinjska region 2007-2013. Regional Development Agency Celje d.o.o., Celje.

Lončar, J. 2008. Industrial, and commercial free zones - definition, meaning and location factors. Geoadria I3, 2, I87-206.

Lorber, L. I999. Slovenia's economic transition in the globalization process. V Geografski zbornik, I33-I66.

Lorber, L. 2006. Funcional changes in Tezno, the industrial zone in Maribor. Revija za geografijo 2,I, 95-Io8.

Miletić R., Miljanović D., Todorović M., 2009. Industrial cities in transition: Problem areas. Bulletin of the Serbian Geographical Society 89, 3, I9I-206. (In Serbian)

Miljanović D., Kovačević-Majkić J., Milanović A., 2004. Environmental analysis in the zone of Corridor X in Serbia. Bulletin of the Serbian Geographical Society 84, 2, I65-I8I. (In Serbian)

Ravbar, M., Bole, D., Nared, J. 2005. A creative milieu and the role of geography in studying the competitiveness of cities: the case of Ljubljana. Acta Geographica Slovenica 45,2, 7-34.

Ravbar, M. 2009. Economic geographical assessment of investments-a development factor in regional development. Acta geographica Slovenica 49, I, I43-I78.

Rowthorn, R., Ramaswamy, R. I999. Growth, trade and deindustrialization. IMF Staff Papers 46, I, I8-4I.

Sitar, M. 2003. New Communication Processes - The Impacts of the Economy on Urban Issues in Slovenia. Viena University of Technology (available at: http://www.corp.at/archive/ CORP2003_Sitar.pdf), 539-544.

Stanilov, K. 2007. The Sost-Socialist City. Urban Form and Space Transformations in Central and Eastern Europe after Socialism. Springer, Dordrecht, $490 \mathrm{pp}$.

Tošić, B., Đorđević, J. 2004. The Settlements of the Belgrade Region. Geographica Pannonica 8, 43-46. Tošić, B., Đorđević, J. 2004. Development centers of the Danube-Morava corridor. Bulletin of the Serbian Geographical Society 84, I, 59-70. (In Serbian) www.conatezno.si www.conatezno.si/o-coni-tezno/ www.dars.si www.rra-celje.si www.tehnopolis-invest.com/index_poslovni_en.php www.tehnopolis.si 